\title{
Fremkalt respons-undersøkelser i klinisk diagnostikk
}

BAKGRUNN Fremkalt respons benyttes for å påvise ledningsforstyrrelser i sentralnervesystemet. Vi gir her en oversikt over bruksområder for fremkalte responser i klinisk nevrofysiologisk diagnostikk, med vekt på koma og demyeliniserende sykdom.

KUNNSKAPSGRUNNLAG Artikkelen bygger på et litteraturs $ø$ k i PubMed og forfatternes lange erfaring med nevrologisk og nevrofysiologisk diagnostikk.

RESULTATER Somatosensorisk fremkalt respons kan gi sikker prognostisk informasjon om manglende oppvåkning allerede 24 timer etter inntruffet anoksisk koma. Dersom koma er forårsaket av en traumatisk hjerneskade, cerebrovaskulær episode eller annen nevrologisk sykdom får man informasjon om hvilke sensoriske hjernestammebaner som er skadet gjennom somatosensorisk fremkalt respons og auditivt fremkalt respons, noe som også kan være nyttig under planlegging av rehabilitering. Normale funn av disse ved koma forårsaket av traume er forbundet med god prognose. Visuelt fremkalt respons kan ofte vise tegn på tidligere gjennomgått optikusnevritt. Somatosensorisk fremkalt respons og auditivt fremkalt respons kan også vise subkliniske lesjoner i sentralnervesystemet og være et supplement i diagnostikk av multippel sklerose.

FORTOLKNING Den kliniske nytteverdien av somatosensorisk fremkalt respons og auditivt fremkalt respons er høy hos komatøse. Fremkalte responser er også viktig i intraoperativ monitorering. Klinisk nytteverdi er høy for visuelt fremkalt respons der spørsmålet om gjennomgått optikusnevritt er avgjørende for diagnostisering av multippel sklerose. Noen utvalgte pasienter som utredes for demyeliniserende sykdom vil ha nytte av full utredning med fremkalte responser.

Fremkalt respons-undersøkelser (evoked potentials, EP) er nevrofysiologiske undersøkelser som gir diagnostisk informasjon om ledningsevnen i viktige ledningsbaner i sentralnervesystemet. Prinsippet er å registrere elektriske svarpotensialer fra ulike deler av nervesystemet etter stimulering av adekvate sanseorganer eller nervebaner, inkludert synsbanene, hørselsbanene, det sensoriske og det motoriske system. Klinisk nytteverdi er kartlagt for mange sykdommer $(1,2)$. Med kognitive responser (event related potentials, ERP) bedømmes oppmerksomhet og mer kompliserte kognitive prosesser.

Fremkalte responser har spesielt stor klinisk nytteverdi ved kartlegging av prognosen hos komatøse etter alvorlig hjerneskade og er også nyttig i utredningen av demyeliniserende sykdommer. Hensikten med denne artikkelen er å gi en kort oversikt over de vanligste former for fremkalte responser samt å beskrive hvordan undersøkelsesmetodene benyttes i klinisk nevrofysiologisk diagnostikk, med hovedvekt på koma og demyeliniserende sykdom.

\section{Kunnskapsgrunnlag}

Artikkelen bygger på et litteratursøk i PubMed med søkeord «evoked potentials» kombinert med «coma», «multiple sclerosis» og «optic neuritis» og på forfatternes lange kliniske erfaring med nevrologisk og nevrofysiologisk diagnostikk.

\section{De vanligste responsundersøkelsene}

Somatosensorisk fremkalt respons

Somatosensorisk fremkalt respons (SEP) er en undersøkelse av det sensoriske system der man stimulerer en perifer nerve, vanligvis medianus og tibialis, med små strømstøt. De viktigste svarpotensialene fra medianus er fremstilt i figur 1. Undersøkelsen brukes vanligvis til å bedømme ledningshastighet og demyelinisering i bakstrengsystemet eller til å bedømme prognosen hos komatøse pasienter (fig 1, venstre utskrift).

\section{Auditivt fremkalt hjernestammerespons}

Auditivt fremkalt hjernestammerespons (BAEP) er en undersøkelse av det auditive system der man stimulerer hørselsbanene ved hjelp av klikkstimulering i en høretelefon. Vi måler flere svarpotensialer fra nervus cochlearis, oliva superior, lemniscus lateralis og colliculus inferior (fig 2). Undersøkelsen kan brukes til å lokalisere sykdom i pontine hørselsbaner og for vurdering av prognose hos komatøse pasienter. Modifisert brukes den av audiologer til å bestemme objektiv høreterskel, da kalles den som regel elektrisk respons audiometri (ERA).

\section{Visuelt fremkalt respons}

Ved visuelt fremkalte responser (VEP) undersøkes synsbanene ved at øyet stimuleres med alternerende rutemønster. Hos pasienter med

\section{Trond Sand}

trond.sand@ntnu.no

Avdeling for nevrologi og klinisk nevrofysiologi St. Olavs hospital

og

Institutt for nevromedisin

Norges teknisk-naturvitenskapelige universitet

\section{Marie Bu Kvaløy}

Nevrosenteret

Seksjon for klinisk nevrofysiologi

Stavanger universitetssjukehus

\section{Tony Wader}

Harald Hovdal

Avdeling for nevrologi og klinisk nevrofysiologi

St. Olavs hospital

Engelsk oversettelse på www.tidsskriftet.no

\section{HOVEDBUDSKAP}

Hos komatøse pasienter kan undersøkelse av somatosensorisk fremkalte responser og auditivt fremkalt hjernestammerespons tidlig i forløpet gi god informasjon om prognose

Visuelt fremkalte responser kan gi informasjon om tidligere gjennomgått optikusnevritt

Intraoperativ monitorering med motorisk fremkalte responser, ev. kombinert med somatosensorisk fremkalte responser og auditivt fremkalt hjernestammerespons, brukes for å forebygge varig skade på nervesystemet 


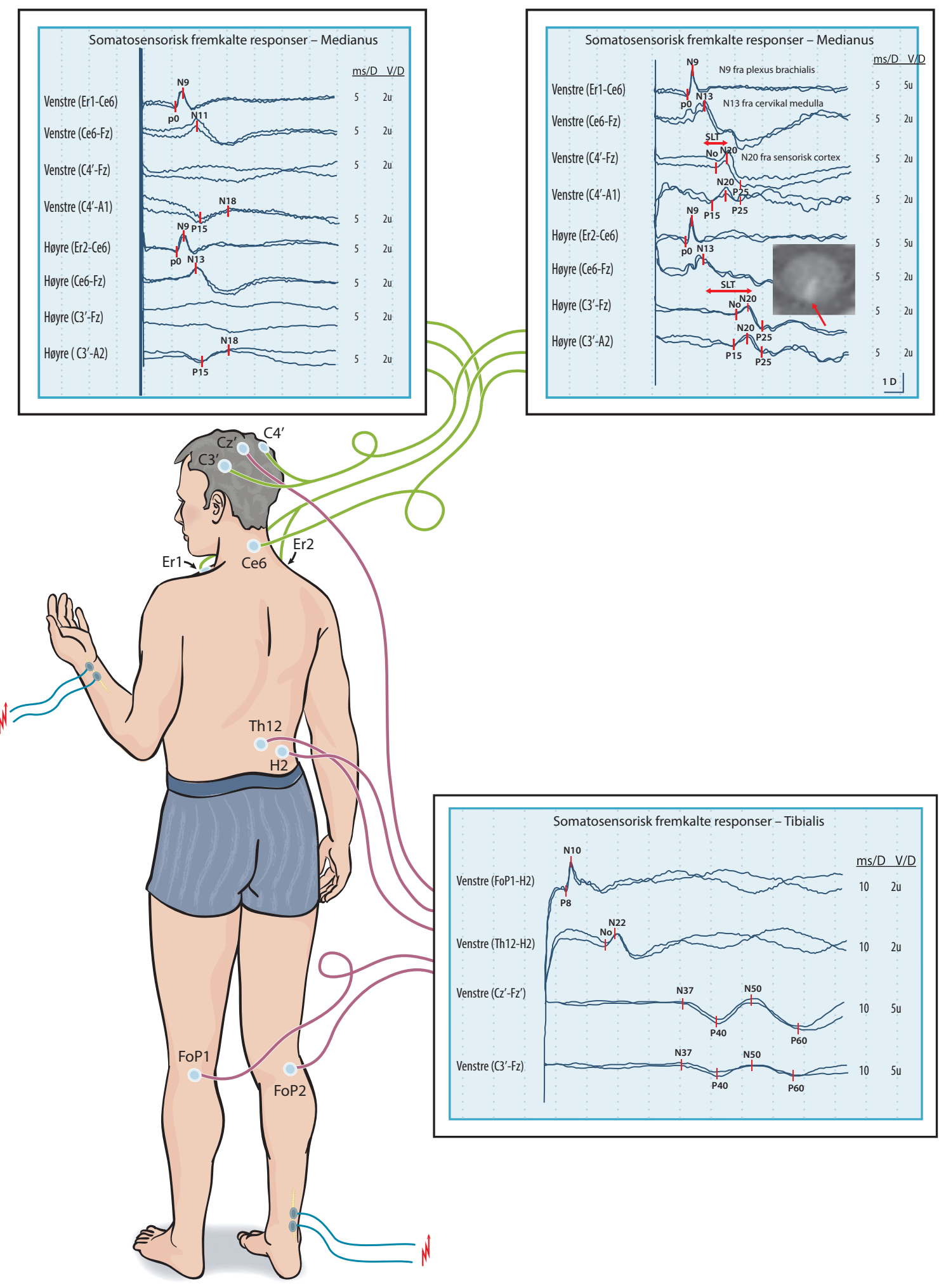

Figur 1 Undersøkelse av somatosensorisk fremkalte responser (SEP). Dette er en undersøkelse av det sensoriske system der man stimulerer en perifer nerve, vanligvis medianus og tibialis, med små strømstøt. De viktigste svarpotensialene er merket av på pasienten. Utskriften øverst til venstre er fra undersøkelse av en pasient med cerebral anoksiskade. Ved SEP-undersøkelser var det manglende svar fra kortikal N20 bilateralt i kanal 3 og 4. Det var normale svar fra plexus brachialis (N9, kanal 1) og cervikal medulla (N13, kanal 2). Bemerk at intakt P15 og N18 i kanal 4 (referenseelektrode på øret) indikerer at hjernestammefunksjonen i lemniscus medialis er intakt. Slike funn indikerer dårlig prognose for oppvåkning. Utskriften øverst til høyre er fra en pasient med parestesier og tyngdefornemmelse i høyre arm og bein. Den viser normale venstresidige medianus SEP-svar fra plexus brachialis (N9), cervikal medulla (N13) og sensorisk cortex (N20), men klart økt N20-latens etter stimulering på høyre side $(24 \mathrm{~ms}$ ) i forhold til venstre (18,7 ms). Dobbeltpiler: Sentral ledningstid (SLT = N20-N13, øvre normalgrense 7,2 ms) er forlenget i bakstreng-/lemniscus medialis-systemet på høyre side $(11,4 \mathrm{~ms})$ i forhold til venstre $(5,4 \mathrm{~ms})$. Innsatt er tverrsnitt fra T2-vektet MR i nivå C2 med en kileformet signaløkning dorsalt som affiserer høyre fasciculus cuneatus (se enkeltpil). Funnene tydet på klinisk isolert syndrom, og ikke sikker multippel sklerose-diagnose. Utskrift nederst til høyre er fra en pasient med intermitterende tåkesyn på det ene øyet de siste par årene. Utskriften viser tibialis-SEP med forlenget latenstid til svarpotensialet P40 fra sensorisk cortex. Sentral ledningstid er også betydelig forlenget ( $P 40-N 22=34,1 \mathrm{~ms}$, øvre normalgrense $22 \mathrm{~ms}$ ). Forlenget P40-latens ble også påvist på høyre side, og både medianus-SEP og visuelt fremkalte responser viste bilateral latensforlenging, mens auditivt fremkalt hjernestammerespons var lett unormal på høyre side. Bemerk normalt perifert svar fra venstre fossa poplitea (FoP1) og normalt lumbalpotensial fra elektroden over Th12 i midtlinjen (N22). Sammenholdt med blant annet MR-funn og spinalvæskeundersøkelser, var disse funnene forenlige med multippel sklerose. Illustrasjon @ J. Engqvist/llumedic 


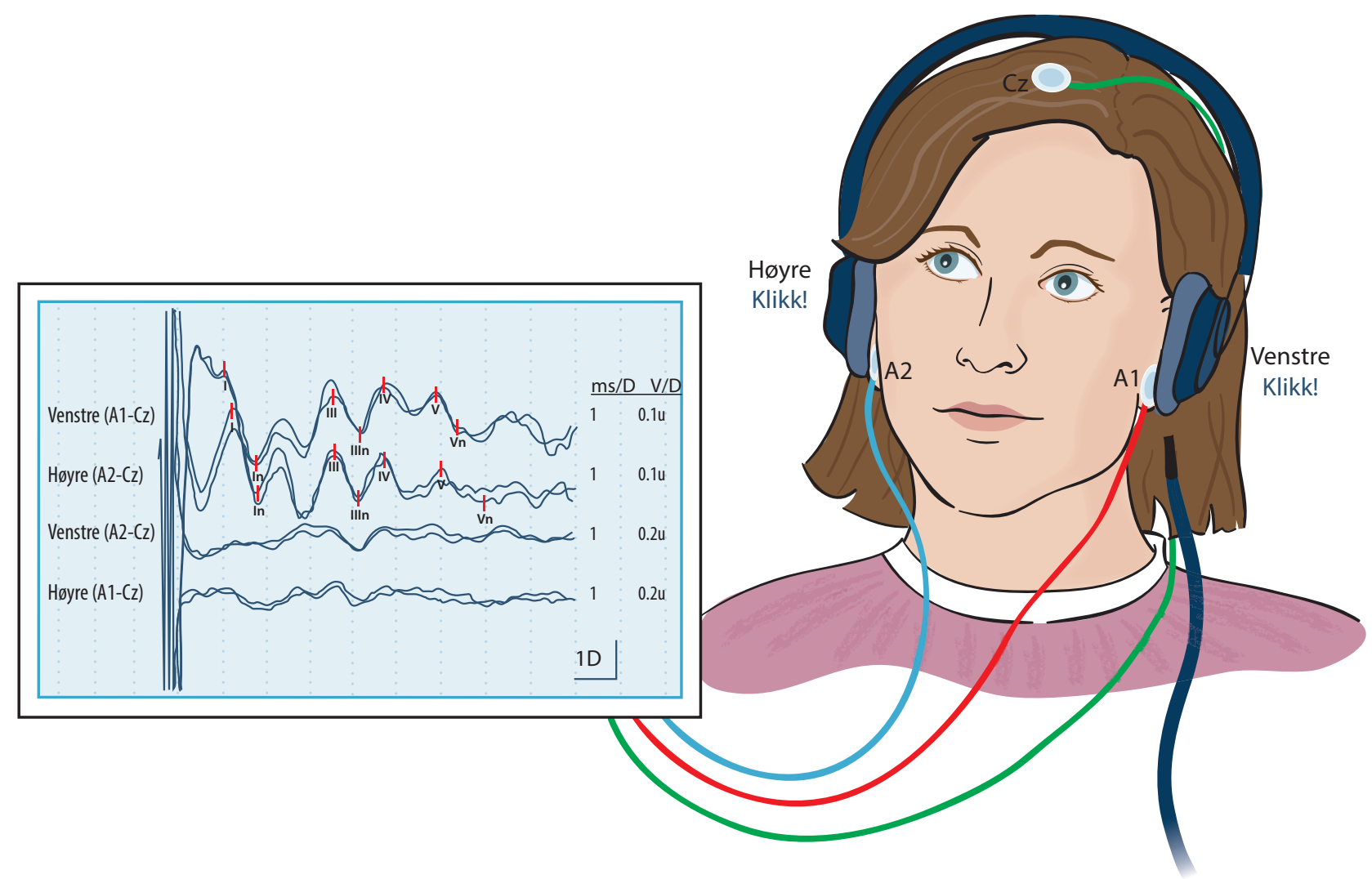

Figur 2 Undersøkelse av auditivt fremkalt hjernestammerespons (BAEP). Dette er en undersøkelse av det auditive system der man stimulerer hørselsbanene ved hjelp av klikkstimulering $i$ en høretelefon. Utskriften er fra en pasient med akutt koma forårsaket av trombose i arteria basilaris. Somatosensorisk fremkalt respons N20 var utslukket bilateralt. Auditivt fremkalt hjernestammerespons viste normal bølge I, III og IV fra venstre øre (kanal 1 med elektrode på venstre øreflipp - A1) og høyre øre (kanal 2 med elektrode på høyre øreflipp - A2). Fra høyre øre er V-bølgen fra colliculus superior amplituderedusert og lite reproduserbar, i tillegg til at avstanden mellom bølge l og Ver klart forlenget $(5,3 \mathrm{~ms})$. Funnet tyder på en strukturell affeksjon i øvre pons nær colliculus superior. Etter hvert forsvant bølge III og IV på høyre side. Kanal 3 og 4 viser avledning fra øret på motsatt side, som ikke ble stimulert. Her vises ikke bølge I (fra cochlea og hørenerven), men avledningen kan hjelpe til å identifisere bølge IV og V. Kombinasjon av utslukket N20 og unormal auditivt fremkalt hjernestammerespons medfører liten sannsynlighet for oppvåkning. Illustrasjon @ J. Engqvist/llumedic

nedsatt visus eller hos små barn bruker man i stedet en lampe med sterkt blinkende lys (flash-VEP). Nerveimpulsene går fra netthinnen gjennom nervus opticus til synscortex. Tre av svarpotensialene brukes i klinisk praksis (fig 3). Undersøkelsen brukes oftest for å dokumentere en tidligere gjennomgått optikusnevritt, for eksempel ved mistenkt multippel sklerose. Den er også nyttig for å følge opp sykdomsprogresjon ved multippel sklerose.

\section{Elektroretinografi}

Elektroretinografi (ERG) utføres ved hjelp av en korneal elektrode (3) og gjøres i noen klinisk nevrofysiologiske laboratorier og øyeavdelinger. Det kan påvise om en retinopati rammer mørkesynet (staver) og/eller dagsynet (tapper). Undersøkelsen brukes for eksempel ved mistanke om retinitis pigmentosa, akromatopsi, kongenital stasjonær nattblindhet, juvenil retinoschisis, Stargardts sykdom, akutt sonal ytre retinopati (AZOOR) og Ushers syndrom.

\section{Motorisk fremkalt respons}

Ved motorisk fremkalte responser (MEP) undersøkes ledningsevnen i kortikospinale baner ved at cortex blir stimulert fra utsiden av hodet med transkranial magnetstimulator eller elektriske pulser. Dette er en slags «omvendt fremkalt respons», fordi svarpotensialene avledes fra muskler. Undersøkelsen kan brukes for å identifisere motorisk cortex for å kunne forebygge lammelser ved nevrokirurgiske inngrep og forsøksvis terapeutisk ved noen smertetilstander og depresjoner (4). Ifølge en omfattende litteraturgjennomgang kan den også brukes som supplerende utredning for å se etter redusert ledningshastighet eller ledningsblokk i pyramidebanen hos utvalgte pasienter med mistanke om motornevronsykdom, multippel sklerose og cervikal myelopati og ved psykogene pareser (5).

\section{Intraoperativ monitorering}

Ved intraoperativ monitorering kan motorisk og sensorisk fremkalte responser samt auditivt fremkalt hjernestammerespons brukes for å forebygge permanent skade på medulla spinalis og andre deler av nervesystemet (6). Motorisk fremkalte responser benyttes ofte for å overvåke funksjonen i de kortikospinale banene ved noen ryggoperasjoner.

\section{Kognitivt fremkalt respons}

Ved kognitivt fremkalt respons (ERP) utføres en oppgave der man evaluerer en stimulus som det skal responderes raskt og riktig på. Samtidig måles endringen i hjernens elektriske aktivitet i ca. ett sekund. P300 er den mest vanlige kognitivt fremkalte responsen (7). Det er rapportert at P300 korrelerer med graden av bevissthet hos pasienter som har overlevd hjertestans (8), men metoden er ikke tilstrekkelig pålitelig til å anvendes som et diagnostisk instrument på enkeltpasienter. Kognitivt fremkalte responser brukes derfor mest i nevropsykologisk forskning. I en internasjonal konsensusrapport har man nylig publisert metodiske retningslinjer (9).

\section{Somatosensorisk fremkalt respons med smerte}

Kortikale responser på kortvarig pulset varmesmerte brukes mest i smerteforskning (10). En ekspertgruppe nedsatt av den europeiske nevrologiforeningen anbefaler at laserfremkalte responser (LEP) også brukes rutinemessig ved spørsmål om nevropatisk smerte og annen tynnfibernevropati fordi responsene blir sterkt svekket dersom A- 


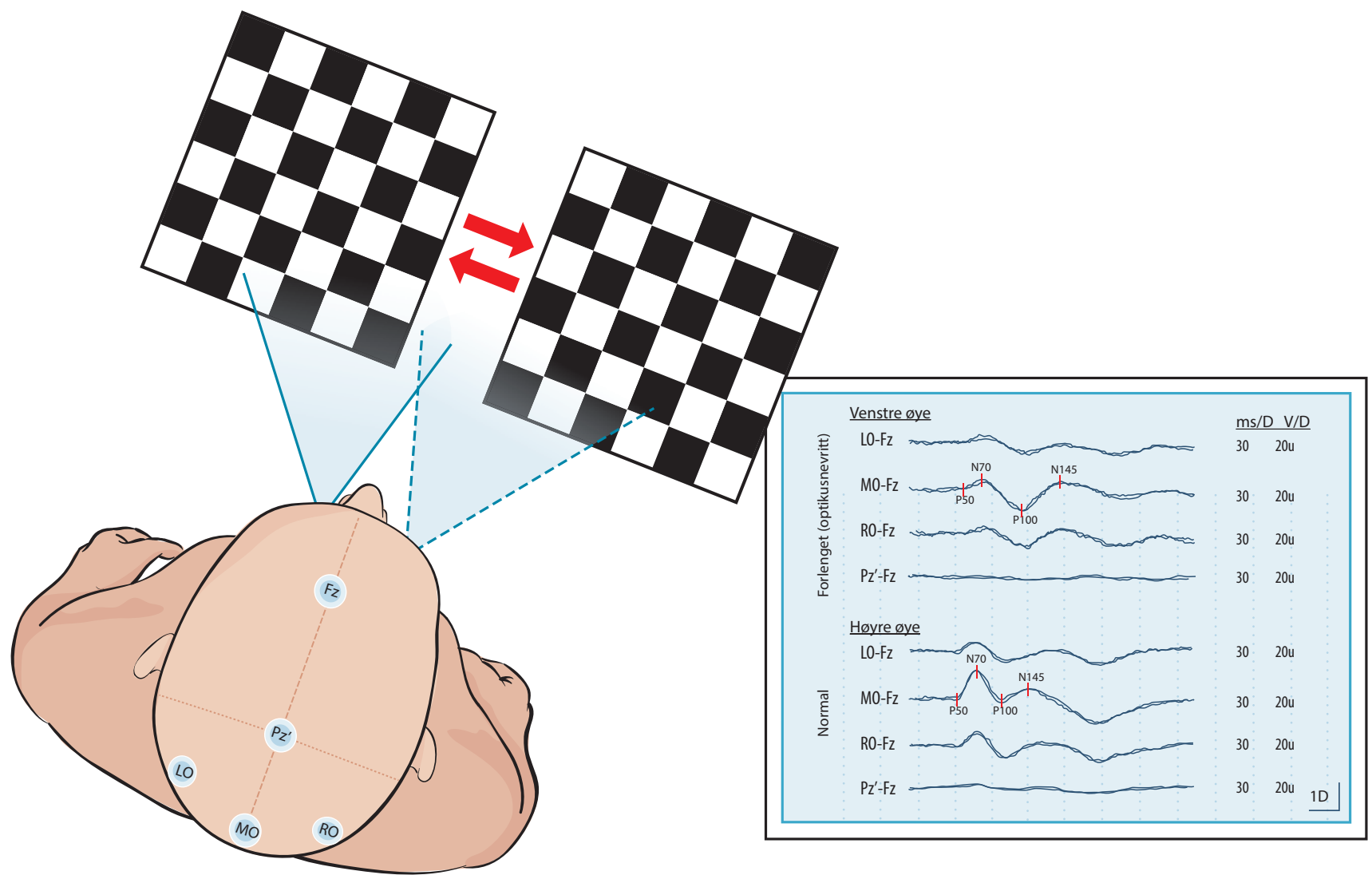

Figur 3 Undersøkelse av visuelt fremkalte responser (VEP) der synsbanene undersøkes ved at hvert øye stimuleres med alternerende rutemønster. Utskriften er fra en pasient der man mistenkte tidligere gjennomgått optikusnevritt. Det er normale VEP-amplituder med symmetrisk respons fra høyre (RO) og venstre (LO) laterale oksipitalregion. VEP-latens til P100 registrert over midtlinjen oksipitalt (MO, kanal 2) er forlenget fra venstre øye (118 ms) iforhold til normal latens på høyre side (98 ms). Funnet bekreftet mistanken om gjennomgått optikusnevritt. Illustrasjon @ J. Engqvist/lllumedic

delta-fibrene ikke fungerer (11). Metoden har ennå ikke fått allmenn utbredelse.

\section{Ved koma}

Somatosensorisk fremkalte responser og auditivt fremkalt hjernestammerespons benyttes i stor og økende grad på intensivavdelinger for å vurdere skadeomfang og prognose hos komatøse pasienter. Det er da helt vesentlig å kunne foreta relativt sett støyfrie målinger og dokumentere komponentene ved gjentakelse av minst to påfølgende replikasjoner av målingene.

Både den generelle prognosen og tolkningen av responssvaret påvirkes av årsaken til koma. Det er fire kliniske hovedgrupper av komatilstander: anoksisk iskemisk hjerneskade etter hjertestans eller respirasjonsstans, traumatisk hjerneskade, cerebrovaskulær sykdom eller ekspansiv prosess i sentralnervesystemet samt metabolsk eller toksisk koma. I de aller fleste tilfeller vil årsaken til koma være kjent etter utredning $\mathrm{i}$ sykehus i løpet av de første 24 timene. I motsetning til elektroencefalografi (EEG) kan ikke undersøkelser av fremkalte responser gi vesentlig etiologisk informasjon, men de kan ofte gi god prognostisk informasjon.
Ved metabolsk/toksisk koma vil normale funn ved somatosensorisk fremkalt respons styrke klinisk mistanke om en reversibel tilstand. Pasienter med traumatiske hodeskader, hjerneblødning eller infarkter vil oftere få komplikasjoner som ødem, herniering eller hydrocephalus, og gjentatte undersøkelser av fremkalte responser er ofte indisert. Anoksi rammer først og fremst diffust $i$ grå substans, og utfallet avhenger av anoksivarigheten.

Somatosensorisk fremkalte responser har stor verdi for tidlig vurdering av prognose ved postanoksisk hjerneskade. Bilateralt fravær av svar fra sensorisk cortex (N20) er den beste prediktoren for manglende oppvåkning, dvs. død, persisterende vegetativ status eller minimal bevissthet, med en spesifisitet på $100 \%(12,13)$ (fig 1). Det samme gjelder dersom anoksipasienter får hypotermibehandling, i alle fall ned til $33^{\circ} \mathrm{C}$ (14). På den annen side kan man ved tilstedeværelse av N20-svar fra sensorisk cortex (på én eller begge sider) ikke tolke dette som sikkert god prognose, fordi omtrent halvparten av disse pasientene ikke vil våkne opp.

I motsetning til EEG er somatosensorisk fremkalte responser ikke vesentlig påvirket av narkose og sedativer, og N20 er målbar selv ved sedasjon til isoelektrisk EEG. Ifølge de sist publiserte internasjonale anbefalingene (15) kan somatosensorisk fremkalte responser utføres allerede 24 timer eller tidligere etter hjertestans, men vi anbefaler ofte, spesielt hos barn (16), å følge utviklingen med gjentatte undersøkelser over flere dager.

Somatosensorisk fremkalte responser er også et nyttig prognostisk mål hos barn, men i motsetning til voksne er god prognose rapportert hos noen få barn selv etter bilateralt fravær av N20 (17). Det er publisert færre artikler om metoden hos barn (17), og funnene må derfor tolkes mer forsiktig enn hos voksne.

Normale funn ved BAEP-undersøkelse har ingen prognostisk verdi ved anoksiske hjerneskader, fordi kortikale nevroner er mer sensitive for hypoksisk-iskemisk skade enn nevroner i hjernestammen. Bevart hjernestammeaktivitet har derimot mye større prognostisk verdi ved traumatiske hjerneskader. Her vil normal auditivt fremkalt hjernestammerespons være et godt tegn, og ved samtidig normale somatosensorisk fremkalte responser er prediktiv verdi for å våkne $90 \%$ og sannsynligheten for godt utfall $75-80 \%$ (13). Patologisk BAEP- 
undersøkelse (spesielt fravær av bølge V) indikerer ponsaffeksjon og er assosiert med død eller persisterende vegetativ status hos over $90 \%$ (15). Bilateralt fravær av somatosensorisk fremkalte responser fra sensorisk cortex er ikke assosiert med død/vegetativ status hos alle hjerneskadepasienter, men gir god prognostisk informasjon også i denne gruppen (18).

Tilsvarende nytteverdi kan man ha hos pasienter med koma av cerebrovaskulær årsak (fig 2). Ved betydelig supratentorial blødning eller infarkt predikerer manglende somatosensorisk fremkalte responser og auditivt fremkalt hjernestammerespons dårlig prognose, mens normale funn gir like usikker prognostisk informasjon som ved anoksiskade (19). Gjentatte responsundersøkelser utover første uke gir lite tilleggsinformasjon i denne gruppen (20).

\section{Ved optikusnevritt og annen demyeliniserende sykdom}

I diagnostikk av multippel sklerose brukes fremkalte responser mindre enn før, fordi de nyeste internasjonale diagnostiske multippel sklerose-kriteriene, som tidligere inkluderte somatosensorisk fremkalte responser, auditivt fremkalt hjernestammerespons og visuelt fremkalte responser (21), nå kun omtaler sistnevnte (22). Det er et hovedpoeng at minst ett multippel sklerose-attakk skal dokumenteres enten med nevrologisk undersøkelse, med visuelt fremkalte responser hos pasienter med tidligere synsforstyrrelse eller med MRfunn i områder som er konsistent med kliniske symptomer (22).

Optikusnevritt forekommer både ved multippel sklerose, som isolert syndrom og ved andre tilstander. Diagnosen er primært klinisk. Visuelt fremkalte responser kan være nyttig for å avdekke subklinisk nevritt, men anses ikke som obligatorisk i akuttfasen (23). De fleste (ca. 90\%) pasienter med gjennomgått optikusnevritt har til dels betydelig forlenget VEP-latens i flere år selv om visus normaliseres $(1,2)$ (fig 3 ).

Neuromyelitis optica (Devics sykdom) er en demyeliniserende sykdom med optikusnevritt og uttalt myelitt (22), der de fleste har antistoffer mot en membranbundet vannkanal (akvaporin 4). Pasientene har redusert VEP-amplitude og normal latenstid (24). Forsinket og/eller amplituderedusert visuelt fremkalte responser kan også skyldes andre tilstander som affiserer nervus opticus, for eksempel tumor, sarkoidose, $\mathrm{B}_{12}$-mangel, nevrosyfilis eller spinocerebellar ataksi (2).

Somatosensorisk fremkalte responser kan fortsatt gi viktig tilleggsinformasjon hos utvalgte pasienter med mistenkt multippel sklerose og usikre MR-funn. Somatosensorisk fremkalte responser er også nyttig hvis MR ikke kan utføres grunnet klaustrofobi. Undersøkelsen er mer sensitiv på underekstremiteter (fig 1, nederste panel) enn medianus (2). Til tross for at den nordamerikanske nevrologiforeningen anså at somatosenso- risk fremkalte responser også kunne være nyttig (25), ble visuelt fremkalte responser som eneste av de fremkalte responsene inkludert i de første MacDonald-kriteriene (26). I de siste revisjonene i 2005 og 2010 (22) er det lagt enda mer vekt på MR og praktisk forenkling av multippel sklerosediagnosen. Vi vil understreke at det fortsatt ikke finnes én sikker diagnostisk laboratoriemarkør for denne sykdommen. MR er en sensitiv, men relativt uspesifikk undersøkelse der noen pasienter kan få en falskt positiv diagnose (27). Fremkalte responser er også etiologisk uspesifikke, men både MR, spinalvæskeundersøkelser og nevrofysiologiske undersøkelser anbefales brukt $\mathrm{i}$ differensialdiagnostikken (28).

Både visuelt fremkalte responser, somatosensorisk fremkalte responser og auditivt fremkalt hjernestammerespons kan avsløre lesjoner som ikke kan oppdages ved MR (29). Fremkalte responser korrelerer med sykdomsvarighet, funksjonell status, sykelighet (30) og sykdomsprogresjon (31). Selv sammenliknet med moderne MR-teknologi vil en komplett (multimodal) utredning med fremkalt respons gi tilleggsinformasjon hos en del pasienter med isolerte kliniske symptomer (32). Fremkalte responser kan derfor ha nytteverdi som objektiv sykdomsmarkør $\mathrm{i}$ behandlingsstudier (33).

\section{Konklusjon}

Undersøkelser av fremkalte responser kan ofte være viktig supplement til informasjon fra EEG, bildedannende metoder og andre laboratorieundersøkelser. Det gjelder spesielt hos komatøse pasienter, men metodene er også nyttige i utredning av optikusnevritt og andre demyeliniserende sykdommer. I intensivavdelinger benyttes ulike fremkalte responser (SEP, BAEP) i stor grad hos komatøse pasienter, og ettersom disse undersøkelsene påvirkes lite av sederende medikamenter og narkose, kan de tidlig gi nyttig klinisk informasjon om skadeomfanget i sentralnervesystemet og si noe om prognosen hos svært mange.

Selv om undersøkelsene er forholdsvis enkle og ikke-invasive, kreves det god og spesialisert opplæring av utførende nevrofysiologiingeniører og nevrofysiologer samt tilstrekkelig erfaring og anvendelse av standardiserte metoder for å få til teknisk gode målinger i kliniske omgivelser $(34,35)$. I fremtiden kan mer effektiv dataprosessering gjøre undersøkelser med bruk av fremkalte responser enda mer sensitive og spesifikke og derved enda bedre egnet for diagnostikk og intraoperativ og annen nevrointensiv monitorering.

\section{Trond Sand (f. 1952)}

er spesialist i klinisk nevrofysiologi og i nevrologi, er seksjonsoverlege, professor og har skrevet doktorgrad om fremkalt respons ved multippel sklerose.

Forfatter har fylt ut ICMJE-skjemaet og oppgir ingen interessekonflikter.

\section{Marie Bu Kvaløy (f. 1974)}

er spesialist i klinisk nevrofysiologi og er overlege.

Forfatter har fylt ut ICMJE-skjemaet og oppgir ingen interessekonflikter.

\section{Tony Wader (f. 1963)}

er spesialist i klinisk nevrofysiologi og i nevrologi og er overlege.

Forfatter har fylt ut ICMJE-skjemaet og oppgir ingen interessekonflikter.

\section{Harald Hovdal (f. 1947)}

er spesialist i nevrologi og er overlege med spesialkompetanse og fagansvar for multippel sklerose.

Forfatter har fylt ut ICMJE-skjemaet og oppgir ingen interessekonflikter.

\section{Litteratur}

1. Walsh P, Kane N, Butler S. The clinical role of evoked potentials. J Neurol Neurosurg Psychiatry 2005; 76 (suppl 2): ii16-22.

2. Chiappa KH. Evoked potentials in clinical medicine. 3. utg. New York, NY: Raven Press, 1999

3. Marmor MF, Fulton AB, Holder GE et al. ISCEV Standard for full-field clinical electroretinography (2008 update). Doc Ophthalmol 2009; 118: 69-77.

4. Wassermann EM, Zimmermann T. Transcranial magnetic brain stimulation: therapeutic promises and scientific gaps. Pharmacol Ther 2012; 133: 98-107.

5. Chen R, Cros D, Curra A et al. The clinical diagnostic utility of transcranial magnetic stimulation: report of an IFCN committee. Clin Neurophysio 2008; 119: 504-32.

6. Michler RP, Unsgård G, Rossvoll I. Nevrofysiologisk monitorering under kirurgi. Tidsskr Nor Legeforen 2013; 133: 306-11.

7. Polich J. Updating P300: an integrative theory of P3a and P3b. Clin Neurophysiol 2007; 118 $2128-48$

8. Guérit JM. Neurophysiological patterns of vegetative and minimally conscious states. Neuropsycho Rehabil 2005; 15: 357-71

9. Duncan CC, Barry RJ, Connolly JF et al. Eventrelated potentials in clinical research: guidelines for eliciting, recording, and quantifying mismatch negativity, P300, and N400. Clin Neurophysiol 2009; 120: 1883-908

10. Cruccu G, Aminoff MJ, Curio $G$ et al. Recommendations for the clinical use of somatosensoryevoked potentials. Clin Neurophysiol 2008; 119 1705-19.

11. Cruccu G, Sommer $C$, Anand $P$ et al. EFNS guidelines on neuropathic pain assessment: revised 2009. Eur J Neurol 2010: 17: 1010-8.

12. Wijdicks EF, Hijdra A, Young GB et al. Practice parameter: prediction of outcome in comatose survivors after cardiopulmonary resuscitation (an evidence-based review): report of the Quality Standards Subcommittee of the American Academy of Neurology. Neurology 2006; 67: 203-10.

13. Guérit JM. Neurophysiological testing in neurocritical care. Curr Opin Crit Care 2010; 16: 98-104.

14. Tiainen M, Kovala TT, Takkunen OS et al. Somatosensory and brainstem auditory evoked potentials in cardiac arrest patients treated with hypothermia. Crit Care Med 2005; 33: 1736-40.

15. Guérit JM Amantini A Amodio P et al. Consensus on the use of neurophysiological tests in the intensive care unit (ICU): electroencephalogram (EEG). evoked potentials (EP), and electroneuromyography (ENMG). Neurophysiol Clin 2009; 39: $71-83$

16. Abend NS, Licht DJ. Predicting outcome in children with hypoxic ischemic encephalopathy Pediatr Crit Care Med 2008; 9: 32-9

17. Carrai R, Grippo A, Lori S et al. Prognostic value of somatosensory evoked potentials in comatose children: a systematic literature review. Intensive Care Med 2010; 36: 1112-26. 
18. Houlden DA, Taylor AB, Feinstein A et al. Early somatosensory evoked potential grades in comatose traumatic brain injury patients predict cognitive and functional outcome. Crit Care Med 2010; 38: 167-74

19. Su YY, Xiao SY, Haupt WF et al. Parameters and grading of evoked potentials: prediction of unfavorable outcome in patients with severe stroke. J Clin Neurophysiol 2010; 27: 25-9.

20. Haupt WF, Pawlik G, Thiel A. Initial and serial evoked potentials in cerebrovascular critical care patients. J Clin Neurophysiol 2006; 23: 389-94

21. Poser CM, Paty DW, Scheinberg L et al. New diagnostic criteria for multiple sclerosis: guidelines for research protocols. Ann Neurol 1983; 13 227-31.

22. Polman CH, Reingold SC, Banwell B et al. Diagnostic criteria for multiple sclerosis: 2010 revisions to the McDonald criteria. Ann Neurol 2011 69: 292-302.

23. Pau D, Al Zubidi N, Yalamanchili S et al. Optic neuritis. Eye (Lond) 2011; 25: 833-42

24. Neto SP, Alvarenga RM, Vasconcelos CC et al. Evaluation of pattern-reversal visual evoked potential in patients with neuromyelitis optica. Mult Scler 2013; 19: 173-8.
25 Gronseth GS, Ashman EJ Practice parameter. the usefulness of evoked potentials in identifying clinically silent lesions in patients with suspected multiple sclerosis (an evidence-based review): Report of the Quality Standards Subcommittee of the American Academy of Neurology. Neurology 2000; 54: 1720-5

26. McDonald WI, Compston A, Edan G et al. Recommended diagnostic criteria for multiple sclerosis: guidelines from the International Panel on the diagnosis of multiple sclerosis. Ann Neurol 2001; 50: $121-7$.

27. Poser CM, Brinar VV. Diagnostic criteria for multiple sclerosis. Clin Neurol Neurosurg 2001; 103 . $1-11$

28. Miller DH, Weinshenker BG, Filippi M et al. Differential diagnosis of suspected multiple sclerosis: a consensus approach. Mult Scler 2008; 14: 1157-74.

29. Sand T, Stovner LJ, Rinck PA et al. Laboratoriediagnostikk ved multippel skelerose. Tidsskr Nor Lægeforen 1991; 111: 2267-70.

30. Sand T. Sulg IA. Evoked potentials and CSF-immunoglobulins in MS: relationship to disease duration, disability, and functional status. Acta Neurol Scand 1990; $82: 217-21$
31. Leocani L, Rovaris M, Boneschi FM et al. Multimodal evoked potentials to assess the evolution of multiple sclerosis: a longitudinal study. J Neurol Neurosurg Psychiatry 2006; 77: 1030-5.

32. Pelayo R, Montalban X, Minoves T et al. Do multimodal evoked potentials add information to MRI in clinically isolated syndromes? Mult Scler 2010; 16: $55-61$.

33. Schlaeger R, D'Souza M, Schindler C et al. Prediction of long-term disability in multiple sclerosis. Mult Scler 2012; 18: 31-8.

34. Todnem K, Sand T, red. Retningslinjer for metoder i klinisk nevrofysiologi. Del 2. Skriftserie for leger. Oslo: Den norske legeforening, 2004

35. Sand T, red. Retningslinjer for metoder i klinisk nevrofysiologi. Del 1. 2.utg. Skriftserie for leger. Oslo: Den norske legeforening, 2008.

Mottatt 27.1. 2012, første revisjon innsendt 8.10 2012, godkjent 7.3. 2013. Medisinsk redaktør

Merete Kile Holtermann. 